\title{
Les occupations littorales du Nord-Cotentin
}

\section{Gérard Vilgrain-Bazin}

\section{OpenEdition \\ Journals}

\section{Édition électronique}

URL : https://journals.openedition.org/adlfi/3926

ISSN : 2114-0502

Éditeur

Ministère de la Culture

Référence électronique

Gérard Vilgrain-Bazin, «Les occupations littorales du Nord-Cotentin » [notice archéologique], ADLFI. Archéologie de la France - Informations [En ligne], Normandie, mis en ligne le 01 mars 2009, consulté le 22 juin 2021. URL : http://journals.openedition.org/adlfi/3926

Ce document a été généré automatiquement le 22 juin 2021.

(c) ministère de la Culture et de la Communication, CNRS 


\title{
Les occupations littorales du Nord- Cotentin
}

\author{
Gérard Vilgrain-Bazin
}

Date de l'opération : 2009 (PI)

1 Depuis bientôt une décennie, ce type d'opération a pour but d'alimenter la carte archéologique d'une part et de fournir des informations complémentaires dans le cadre de trois PCR: «Les premiers Hommes en Normandie » (D. Cliquet), «Étude du milieu littoral» (C. Billard) et "Presqu'île de la Hague» (C. Marcigny). D'autre part, des découvertes fortuites qui nous sont signalées par nos informateurs, sont également prises en compte.

2 Dans le premier cas, la découverte d'une petite série lithique (environ une trentaine d'artefacts roulés) a été collectée en partie sommitale d'estran au lieu-dit « Le Perrey », entre l'anse du Cap Lévi et l'anse du Pied Sablon sur la commune de Fermanville. Cette modeste série se rapporte au Paléolithique moyen. Dans le second cas, ce sont les vestiges de parcs à huîtres au lieu-dit «Les Sablons » qui nous ont été indiqués par un historien de la commune de Regnéville-sur-Mer. Créée vers 1840, la concession cessa son activité définitive en 1912 après bien des déboires depuis 1878. Dans le troisième cas, c'est le porteur lui-même du projet qui nous a indiqué la présence d'une structure de combustion dans la micro-falaise au lieu-dit "Les Ecameland», commune d'Auderville. Compte tenu de l'aménagement, il pourrait s'agir d'un foyer à pierres chauffées comme on en trouve régulièrement sur les côtes de la Hague et dont les datations ${ }^{14} \mathrm{C}$ réalisées donnent comme résultat la période Néolithique au sens large.

3 En ce qui concerne les découvertes fortuites, on peut faire mention :

4 - d'un indice de site vraisemblablement attribuable à la période protohistorique, dans une plaque de tourbe située sur l'estran de la commune de Néville-sur-Mer ;

5 - au lieu-dit « Le Grand Mont », commune de Réville, c'est la découverte d'une hache polie en dolérite qui nous a été communiquée ; 
- sur la commune de Quettehou, nous avons repris une prospection sur la localisation du château du Mont Haguez, dont il est fait état par le poète normand du XII ${ }^{e}$ s. Wace dit aussi Guace ou Vistace, dans le Roman de Rouoù il est décrit le site du château d'Abilant, dénommé Mont Hagueis, comme situé sur l'une des collines à la limite des communes de Quettehou et de La Pernelle (Michel de Boüard, 1955);

- un muret de pierres sèches bordant un chemin qui conduit à une plateforme qui pourrait correspondre à l'emplacement du château et dont plusieurs parcelles sont identifiées « Mont-Haguais » sur les plans du cadastre actuel ;

- à Vauville, entre la Crecque et la Rue, plusieurs tessons de céramique issus des limons de la falaise ont été collectés, ils sont attribuables à la période médiévale XII ${ }^{\mathrm{s}}$ s.-

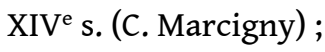

9 - au lieu-dit «La Vieille Église » situé sur la commune d'Omonville-la-Petite, c'est une structure " énigmatique » qui nous a été signalée suite à un démaigrissement du haut de plage, à l'issue de violentes tempêtes. Il semble s'agir des vestiges d'un pavage constitué de petits blocs de roches locales disposés debout et que l'on a pu observer sur une longueur de $16 \mathrm{~m}$ environ. Néanmoins, ce pavage a fortement subi des effets de tempêtes sous la forme de croissants de plage : ceux-ci comportent des cornes (parties longilignes élevées) et des creux ouverts vers le large. Leur formation, lorsqu'il s'agit de galets, ce qui est le cas ici, est due à des périodes où les grosses vagues dominent (André Guilcher et Jean-Pierre Coutard) ;

- enfin, les propriétaires du manoir de La Drouetterie au Mesnil-au-Val nous ont fait part de la présence d'un objet en bois de grande dimension, situé à la confluence de deux petits ruisseaux à très fort débit. Il pourrait s'agir d'un aménagement hydraulique réalisé, dans le cadre de travaux de drainage, par Gilles de Gouberville au XVI ${ }^{\mathrm{e}} \mathrm{s}$.

\section{AUTEURS}

\section{GÉRARD VILGRAIN-BAZIN}

BEN 